\title{
Głoszenie orędzia Starego Testamentu. Refleksje homiletyczne
}

Całe Pismo Święte jest podstawowym źródłem kaznodziejskiej posługi słowa i dlatego Stary Testament powinien mieć w niej swoje ważne miejsce. Przed reformą lekcjonarza po II soborze watykańskim czytania ze Starego Testamentu przypadały w niektóre święta, a najczęściej w dni w ciągu tygodnia ${ }^{1}$. Dlatego też kaznodzieje głoszący słowo Boże w niedziele rzadko powoływali się na Stary Testament. W sposób ogólny o Piśmie Świętym Starego Testamentu nauczano w kazaniach katechizmowych. Szczegółowo czynili to katecheci, którzy np. dzieciom w klasie III opowiadali Stary Testament jako historię biblijną. Po II soborze watykańskim weszły do liturgii liczne teksty ze Starego Testamentu i dlatego powstał problem odpowiedniego głoszenia ich przesłania.

Zadajemy zatem pytania: czy i w jakim zakresie zajmują się tym zagadnieniem homileci? W jaki sposób kaznodzieje czerpią ze Starego Testamentu, szczególnie z tekstów liturgicznych? Co należy 
akcentować w głoszeniu tych perykop, jak łączyć przesłanie Starego Testamentu z orędziem Nowego, a przede wszystkim z Ewangelią? Jakie zasady obowiązują kaznodziejów, a szczególnie głosicieli homilii, którzy mają do dyspozycji lekcjonarz niedzielny i świąteczny? Przedstawimy więc kolejno: stan badań homiletycznych, naukę Kościoła, historiozbawczy kontekst orędzia Starego Testamentu, łączenie tekstów starotestamentowych z tekstami nowotestamentowymi oraz wskazania i wnioski.

\section{Stan badań homiletycznych i potrzeba ich kontynuacji}

Na znaczenie Starego Testamentu w kaznodziejstwie zwrócili uwagę niektórzy dawniejsi homileci² ${ }^{2}$ Stopniowo coraz bardziej doceniano rolę Starego Testamentu w kaznodziejstwie, ale nie uwydatniano jeszcze wyraźnie jego historiozbawczego znaczenia. Stary Testament był głównie źródłem cytatów, argumentów, przykładów i ilustracji. Refleksja homiletyczna na temat roli Starego Testamentu w kaznodziejstwie nabrała znaczenia, gdy w 1963 roku II Sobór Watykański wysunął postulat, aby „obficiej zastawić wiernym stół słowa Bożego [...] otworzyć skarbiec biblijny” (KL 51). W odpowiedzi na to opracowano

2 Ks. Władysław Krynicki m.in. zwrócił uwagę na piękno form językowych Starego Testamentu, takich jak opowiadanie, opis i charakterystyka, figury retoryczne, a także podkreślił wzniosłość treści i ekspresję uczuciową wybranych tekstów. Wymowa święta, wyd. 2, Poznań 1921, s. 127-128. Ks. Ildefons Bobicz zachęcał kaznodziejów do czytania Pisma Świętego, w tym Starego Testamentu, podał krótkie wprowadzenia do jego ksiąg i zwrócił uwagę na znaczenie mesjańskich proroctw i figur w głoszeniu kazań. Źródła kaznodziejstwa. Pismo Święte, w: Homiletyka duszpasterska, Kielce 1935, s. 175-179, 182-187, 218. Natomiast ks. Zygmunt Pilch uwydatnił związek między Starym i Nowym Testamentem, wskazał na wypełnienie się w Chrystusie starotestamentowych proroctw i zapowiedzi oraz uwydatnił znaczenie sensu typicznego. Wykład zasad kościelnej wymowy, Poznań 1958, s. $290-292,306-307$. 
nowy lekcjonarz mszalny. Od tego czasu upłynęło już ponad czterdzieści lat i rozwinęła się homiletyczna refleksja na temat wiernego głoszenia biblijnego kerygmatu i jego aktualizacji. Jakie zatem wskazania podają polscy homileci w odniesieniu do kaznodziejskiego głoszenia przesłania tekstów ze Starego Testamentu?

Wydana w 2007 roku Polska bibliografia homiletyczna 1945-2000³ zawiera indeks rzeczowy, w którym nie ma hasła "Stary Testament”, lecz jest ogólne hasło „Pismo Święte”. Pod tym hasłem zanotowano łącznie 135 pozycji na ich ogólną liczbę 2 930, w tym około 2100 drukowanych i około 830 w formie maszynopisów, będących zwykle pracami dyplomowymi. Wypowiedzi homiletów na temat głoszenia wybranych aspektów orędzia Starego Testamentu można spotkać w czterech artykułach i dwóch pracach dyplomowych, które mieszczą się w ramach ogólnego zagadnienia: Pismo Święte w kaznodziejstwie. Zaledwie trzy publikacje drukowane w całości dotyczą kazania na temat Starego Testamentu. Należą tu dwie publikacje z homiletyki katolickiej ${ }^{4}$ i jedna publikacja $z$ homiletyki protestanckiej ${ }^{5}$. Na znaczenie Starego Testamentu w historiozbawczym głoszeniu kerygmatu cudów Jezusa zwrócił uwagę Jan Twardy ${ }^{6}$. Autor ten, pisząc o aktualizacji słowa Bożego, uwydatnił zasadę jedności Pisma Świętego i podkreślił znaczenie perspektywy zapowiedź-wypełnienie oraz związanej z nią interpretacji typologicznej ${ }^{7}$.

Można powiedzieć, że współcześni homileci polscy słabo interesują się głoszeniem orędzia Starego Testamentu. Piszą oni przede wszystkim ogólnie o Piśmie Świętym w kaznodziejstwie, korzystaniu z hermeneutyki biblijnej, głoszeniu kerygmatu lub szczegółowo

3 Oprac. W. Przyczyna, L. Szewczyk, Kraków 2007.

4 T. Dzięgiel, Stary Testament w posłudze słowa, "Materiały Problemowe” 10 (1978) nr 6, s. 127-134.

5 J. Gryniakow, Teksty Starego Testamentu w homiletyce chrześcijańskiej, „Rocznik Teologiczny ChAT" 28 (1986) 1, s. 21-35.

6 Głoszenie cudów Jezusa dzisiaj, Kielce 2001, s. 49-64.

7 Aktualizacja słowa Bożego w kaznodziejstwie, Przemyśl 2009, s. 111-120. 
o przesłaniu wybranych tekstów. Podkreślając aspekt historiozbawczy, zwracają również uwagę na znaczenie Starego Testamentu w kaznodziejstwie, co odpowiada charakterystycznym trendom posoborowej odnowy kerygmatycznej. Skoro jednak polscy homileci rzadko piszą o problemie głoszenia orędzia Starego Testamentu, dzieje się tak być może dlatego, że nie czują się kompetentni w tej dziedzinie.

Należy dodać, że w polskiej homiletyce przeprowadzono badania homilii z zakresu aktualizacji kerygmatu czytań biblijnych przeznaczonych na wybraną niedzielę lub uroczystość. Wymagało to poznania sposobów czerpania z czytań ze Starego Testamentu przez autorów homilii. Do 2005 roku w kilku polskich uczelniach powstały 34 tego rodzaju prace dyplomowe. W naszej refleksji nawiązujemy do 10 takich prac, których autorzy przeanalizowali w sumie 627 homilii. W każdej z nich pytali o korzystanie z kerygmatu poszczególnych czytań, w tym także z czytań ze Starego Testamentu. Autorzy homilii w ogromnej większości nawiązywali do Ewangelii, a mała ich część, około 10-15 proc., połączyła kerygmat Ewangelii z przesłaniem czytania ze Starego Testamentu. Znalazło to wyraz głównie w zacytowaniu tego tekstu lub w ukazaniu jego związku tematycznego z Ewangelią, rzadko jednak na zasadzie historiozbawczej. A trzeba pamiętać, że publikowane homilie ze swej istoty powinny być wzorcowe, aby mogły dobrze służyć głosicielom słowa Bożego ${ }^{8}$. Bardzo aktualna jest zatem refleksja homiletyczna na temat głoszenia orędzia Starego Testamentu i jego powiązania z kerygmatem Nowego

8 Można zatem ogólnie stwierdzić, że w polskich homiliach nie zauważa się częstego głoszenia przesłania Starego Testamentu. Autorzy homilii nawiązują głównie do Ewangelii, a część z nich także do drugiego czytania. Należy dodać, że autorzy 65 homilii nie nawiązali do czytań biblijnych, czyli w przeszło 10 proc. badanych jednostkach kaznodziejskich brak jest związku z czytaniami liturgicznymi, a tym samym brak nawiązania do Starego Testamentu. Wynika z tego, że autorzy badanych homilii drukowanych odznaczają się małą wrażliwością na potrzebę pełnego korzystania ze stołu słowa Bożego, a tym samym pomijają historiozbawczy aspekt homilii. J. Twardy, Aktualizacja słowa Bożego, s. 330-333. 
Testamentu. Jest to także konieczne ze względu na aktualizację kerygmatu czytań biblijnych przeznaczonych na określony dzień liturgiczny. Należałoby zatem nadal badać polskie pomoce kaznodziejskie pod kątem uwzględniania w nich Starego Testamentu. Wzorem w tym względzie powinny być homiletyczne komentarze biblijne na niedziele i święta ${ }^{9}$. Dokonał tego w pewnym zakresie Augustyn Jankowski ${ }^{10}$, ale jego czterotomowy komentarz ma raczej ograniczony wpływ na kaznodziejów i homiletów.

Chcąc głębiej wniknąć w interesujący nas problem, trzeba poznać homiletykę obcojęzyczną, a przede wszystkim teorię kaznodziejstwa w języku niemieckim, w której obok siebie występują refleksje katolicka i protestancka. To przede wszystkim homileci protestanccy piszą na temat kaznodziejskiego głoszenia orędzia Starego Testamentu. Kierują się oni zasadą sola Scriptura i w związku z tym pod kątem kerygmatycznym omawiają pojedyncze teksty biblijne oraz ich grupy, w tym także czytania ze Starego Testamentu, które występują w ich lekcjonarzu.

Teorię głoszenia orędzia Starego Testamentu spotykamy głównie w podręcznikach homiletyki, których autorzy przeznaczyli odpowiednie miejsce na omawianie przesłania grup tekstów biblijnych. Znamienne są tytuły tych części teorii głoszenia słowa Bożego: Kazanie o tekstach Starego Testamentu ${ }^{11}$, Znaczenie Starego Testamentu dla ka-

9 Należy zauważyć, że na początku lat osiemdziesiątych minionego wieku polscy bibliści sporządzili czterotomowe komentarze, w których osobno objaśnili każde czytanie niedzielne w cyklu ABC i na czytanie świąteczne (S), ale nie uwydatnili powiązania historiozbawczego lub tematycznego pomiędzy perykopami, a szczególnie pomiędzy perykopą ze Starego Testamentu i Ewangelią. Komentarze biblijne do czytań mszalnych ABCS, t. I-IV, red. J. Homerski, S. Łach, Lublin 1981.

10 Przy stole słowa. Objaśnienia do czytań mszalnych na niedziele i święta, t. I-IV, Kraków 1999-2000.

11 W. Trillhaas, Evangelische Predigtlehre, Aufl. 4, München 1955, s. 96-107; W. Schütz, Probleme der Predigt, Göttingen 1981, s. 81-87; F. Winter, Die Predigt, w: Handbuch der Praktischen Theologie, Bd. 2, red. H. Ammer [ i in.], Berlin 1974, s. 249-252; H. M. Müller, Homiletik, Berlin 1996, s. 222-227. 
zania $^{12}$; Używanie Starego Testamentu $w$ chrześcijańskim kazaniu ${ }^{13}$, Doświadczenie chrześcijan a Stary Testament ${ }^{14}$, Hermeneutyka Starego Testamentu ${ }^{15}$. Dobitnie wyraził ten problem Wilfried Engemann, który postuluje, aby „starotestamentowe teksty głosić po chrześcijańsku”16 lub w duchu chrześcijańskim. Widać więc, że w artykułach protestanckich zarysowują się dwa kierunki:

1) kazanie bazujące na tekstach ze Starego Testamentu, zgodnie z tekstualną zasadą homiletyki i kaznodziejstwa (Textpredigt);

2) uwydatnianie w kazaniu związku między tekstami ze Starego Testamentu i orędziem Nowego Testamentu, co wyraża historiozbawcze znaczenie tych perykop.

Ze strony katolickiej interesującym nas problemem w duchu ekumenicznym zajął się niemiecki homileta Bruno Dreher, który w książce Biblisch Predigen zamieścił Exkurs: Die alttestamentliche Predigt ${ }^{17}$. W tym artykule zajął się homiletyczno-hermeneutycznymi zagadnieniami, a $\mathrm{w}$ aneksie do niego podał 40 pozycji związanych $\mathrm{z}$ hermeneutyką Starego Testamentu i kaznodziejstwem na jego temat ${ }^{18}$.

Ważną niemiecką pozycją homiletyczną jest zbiorowe wydanie Die vergessene Wurzel. Das Alte Testament in der Predigt der Kirchen $^{19}$. Spośród ośmiu artykułów dwa wprost dotyczą teorii ka-

12 F. Mildenberger, Kleine Predigtlehre, Stuttgart 1984, s. 96-113; W. Klippert, Vom Text zur Predigt, Wuppertal 1995, s. 45-47.

13 R. Conrad, M. Weber, Protestantische Predigtlehre, Tübingen 2012, s. 50-61.

14 H. Hirschler, Biblisch predigen, Hannover 19923, s. 198-212.

15 J. Ziemer, Der Text, w: Handbuch der Predigt, red. K. H. Bieritz [i in.], Berlin 1990, s. 222-224.

16 W. Engemann, Einführung in die Homiletik, Tübingen 2002, s. 282-289.

17 Stuttgart 1968, s. 63-78.

18 B. Dreher, Biblisch predigen..., dz. cyt., s. 76-78. Teorię przepowiadania Brunona Drehera opracował w Polsce Herbert Simon w swej pracy doktorskiej: Kazanie biblijne. Teoria przepowiadania Bruno Drehera (1911-1971), Opole 1995, s. 60-66.

19 Red. R. Zerfaß, H. Poengsen, Würzburg 1990. Publikacja jest owocem sympozjum homiletów w Würzburgu w 1988 roku. Na końcu zawiera ona bibliografię liczącą przeszło 400 pozycji, związanych z egzegezą i teologią Starego Testamentu. 
zań o Starym Testamencie ${ }^{20}$, a jeden pośrednio, gdyż dotyczy wyboru perykop ze Starego Testamentu w posoborowym lekcjonarzu ${ }^{21}$. Natomiast pięciu pozostałych autorów przybliżyło pomocne dla homiletów i kaznodziejów zagadnienia związane z egzegezą i teologią Starego Testamentu ${ }^{22}$.

Z kolei należy zapytać, jak w praktyce kaznodziejskiej w języku niemieckim wygląda głoszenie orędzia Starego Testamentu? Przodują tu protestanckie pomoce do kazań niedzielnych i świątecznych ${ }^{23}$, jak na przykład Göttinger Predigt Meditationen (Göttingen 1946-), które m.in. zawierają medytacje kaznodziejskie do tekstów ze Starego Testamentu. Natomiast ze strony katolickiej opracowano osiemnastotomowe dzieło Neues Predigtwerk ${ }^{24}$, w którym znajdziemy komentarze biblijne, medytacje i kazania na wszystkie czytania z niedzielnego cyklu ABC oraz na uroczystości i święta. Autorzy tych pomocy nie łączą jednak czytania ze Starego Testamentu z Ewangelią. Podobnie jest $w$ takich czasopismach kaznodziejskich jak „Gottes Wort im Kirchejahr” (Würzburg 1940-) i „Der Prediger und Katechet" (München 1850-). Zawierają one osobne homilie na: teksty ze Starego Testamentu, II czytanie i Ewangelię. Brak więc uwy-

20 Herbert Poengsen (Was macht die christliche Predigt aus dem Alten Testament, VW, s. 9-28) uczy, jak korzystać ze Starego Testamentu w kazaniu chrześcijańskim, a Rolf Zerfass (Texte und Kontexte. Zur Erschließung alttestamentlicher Perikopen im Predigtgespräch, VW, s. 174-191) wskazuje, jak należy przedstawić orędzie Starego Testamentu w rozmowie, która zmierza do przygotowania kazania.

21 E. Nübold, Zur Auswahl der Perikopen des Alten Testaments in der nachkonziliaren katholischen Perikopenordnung, VW, s. 29-42.

22 Norbert Lohfing przybliżył nauczanie proroków Izraela jako wieszczów i krytyków społeczeństwa (VW, s. 43-65); Wolfgang Raupach ukazał interpretację społecznych uwarunkowań w nauczaniu prorockim (VW s. 66-88); Erich Zenger napisał o cierpieniu Izraela w kontekście jego wiary w Boga w oparciu o słowa Ps 44, 25 (VW, s. 89-119); Friedrich Wilhelm Marquart zajął się problemem wiary w Boga w czasie wygnania Izraela i w kontekście współczesnego ateizmu (VW, s. 120147); Aleks Stock zwrócił uwagę na typologiczną egzegezę w powiązaniu z teologią zielonoświątkowców (VW, s. 149-173).

23 B. Dreher, Biblisch predigen..., dz. cyt., s. 76-78.

24 Bd. I-XVIII, red. B. Dreher, Graz 1970-1972. 
datnienia aspektu historiozbawczego w głoszeniu orędzia Starego Testamentu i Ewangelii, co wskazuje na rozbieżność praktyki kaznodziejskiej z wymogami Kościoła wyrażonymi m.in. we wprowadzeniu do Lekcjonarza.

Tak więc orędzie Starego Testamentu pozostaje nadal w pewnym stopniu zapomnianym korzeniem wiary, mimo odnowy lekcjonarza i postulatów wielu homiletów, aby je głosić. Dlatego potrzebna jest dalsza refleksja w tej dziedzinie; ma ona przed sobą szerokie perspektywy ${ }^{25}$.

\section{Wskazania dokumentów Kościoła}

Mówiąc o głoszeniu przesłania Starego Testamentu w kaznodziejskiej posłudze słowa, trzeba najpierw sięgnąć do soborowych i posoborowych dokumentów Kościoła. Tam bowiem zawarte są wypowiedzi na temat jedności Biblii, związku między Starym i Nowym Testamentem oraz znaczenia Starego Testamentu w nauczaniu Kościoła. A oto chronologiczny wykaz głównych dokumentów: Konstytucja dogmatyczna o Objawieniu Bożym Dei Verbum (1965: 1416); Katechizm Kościoła Katolickiego (1997, 2002: 120-123, 128-130); dwa dokumenty Papieskiej Komisji Biblijnej: Interpretacja Biblii w Kościele (1993: III A2) oraz Naród żydowski i jego Święte Pisma w Biblii chrześcijańskiej (2001: 19); adhortacja apostolska Benedykta XVI o słowie Bożym w życiu i misji Kościoła Verbum Domini (2010: 39-44) oraz wydane przez Kongregację ds. Kultu i Dyscypliny Sakramentów Dyrektorium homiletyczne (2015: 18-19, 23-25, 38, 51, $57,81,146,148)$.

Znamienne jest to, że we wszystkich wymienionych dokumentach uwydatniono jedność Pisma Świętego, a więc ścisły związek, jaki 
zachodzi między Starym i Nowym Testamentem, co ma istotne znaczenie dla głosicieli słowa Bożego. W adhortacji apostolskiej Verbum Domini Benedykt XVI podaje ważne wskazania, które uczą właściwego interpretacji Starego Testamentu w głoszeniu słowa Bożego. U jej podstaw leży wewnętrzna jedność całego Pisma Świętego, ponieważ jedno jest słowo Boże (VD 39). Papież cytuje słowa Hugona od św. Wiktora: „Całe Pismo Święte jest jedną księgą, a tą jedną księgą jest Chrystus, ponieważ całe Pismo Święte mówi o Chrystusie i wypełnia się w Chrystusie" (VD 39). Nie jest to księga w dosłownym tego słowa znaczeniu, ale stanowi „zbiór tekstów literackich, których redagowanie trwało ponad tysiąc lat i której poszczególnych ksiąg nie da się łatwo wyodrębnić jako wewnętrznej całości; istnieją natomiast widoczne powiązania między nimi” (VD 39). Jest to zatem „jedyne słowo Boga skierowane do nas”, a „osoba Chrystusa nadaje jedność wszystkim «Pismom» w powiązaniu z jedynym «Słowem»" (VD 39). Dlatego wewnętrzna jedność całej Biblii jest decydującym kryterium poprawnej hermeneutyki jej tekstów (KO 12), w tym także tekstów ze Starego Testamentu. Liturgiczne czytania ze Starego Testamentu kończymy aklamacją: „Oto słowo Boże”, czyli słowo jedynego Boga. Dlatego „Pisma nie można odrzucić” (J 10,35), jest ono dla chrześcijan ciągle aktualne (por. Rz 15, 4; 1 Kor 10, 11). W Starym Testamencie znajdują się korzenie chrześcijaństwa, a Nowy Testament dowodzi ciągłości objawienia Bożego. Mówi o postępie, spełnieniu się zapowiedzi i przewyższaniu starego orędzia przez nowe, np. kontynuacją ofiarniczego kultu Starego Testamentu jest ofiara Chrystusa, która w Nim osiągnęła nigdy dotąd niespotykaną doskonałość (VD 40). Jednak misterium paschalne zawiera w sobie także „wyraźne aspekty braku ciągłości względem instytucji Starego Testamentu” (DV 40). Ponieważ jest jedna Biblia, której autorem jest jedyny Bóg, Ojciec działający przez Syna w Duchu Świętym i jedno jest słowo Boże, dlatego Stary Testament należy głosić w kontekście teocentrycznym i trynitarnym. 
Benedykt XVI wskazuje również na „mroczne” karty Biblii, gdyż objawienie Boże jest zakorzenione w historii, a „zamysł Boży odsłania się w niej stopniowo i urzeczywistnia się powoli na kolejnych etapach pomimo oporu ludzi. Bóg wybiera lud i cierpliwie go wychowuje. Objawienie jest dostosowane do kulturowego i moralnego poziomu odległych epok, a zatem relacjonuje fakty i zwyczaje, jak na przykład podstępne zabiegi, przemoc, rzezie ludzkości, nie mówiąc wyraźnie, że są one niemoralne; wyjaśnieniem tego jest kontekst historyczny, ale może to zaskakiwać dzisiejszego czytelnika, zwłaszcza gdy zapomina się o licznych «mrocznych» zachowaniach, których nigdy nie brakowało na przestrzeni wieków i nie brak również w naszych czasach" (VD 42). Zdecydowanie przeciwstawiają się złu prorocy, którzy dostrzegają niesprawiedliwość i przemoc, zbiorową lub indywidualną, a przez to współpracują z Bogiem w przygotowaniu ludu do przyjęcia Ewangelii (por. VD 42). Jeżeli podobne trudne teksty występują w liturgii, kaznodzieja nie może ich pomijać, ale powinien tłumaczyć wiernym, tym bardziej gdyby budziły w nich wątpliwości. Może się to okazać potrzebne także w ciągu tygodnia, kiedy w sposób ciągły czytamy teksty ze Starego Testamentu.

Homileci i kaznodzieje powinni pamiętać o dokumencie Papieskiej Komisji Biblijnej Naród żydowski i jego Święte Pisma w Biblii chrześcijańskiej. Dokument ten zawiera pouczenia o związku Starego Testamentu z Nowym: konieczne było wypełnienie się Pisma, na co wskazuje zgodność i różnica między Pismami Nowego i Starego Przymierza (NŻP 6-8). Skoro obydwa Testamenty wzajemnie się odnoszą do siebie, konieczna jest też relektura Starego Testamentu w świetle Chrystusa, istotny jest powrót do sensu wyrazowego, nie zaś propagowanie i narzucanie tekstom Starego Testamentu sensu alegorycznego (NŻP 19-20). W tłumaczeniu słowa Bożego Kościół zawsze wskazywał na jedność planu Bożego w obydwu Testamentach i uczył o jego wypełnianiu się w dziejach zbawienia (NŻP 21). Papieska Komisja Biblijna wskazuje na ciągłość objawienia 
i działania Boga, na to, że nowe wydarzenie zgodne jest z tym, co było wcześniej zapowiedziane; „Nowy Testament podejmuje w pełni wszystkie wielkie tematy teologii Izraela w ich potrójnym odniesieniu do teraźniejszości, przeszłości i przyszłości” (NŻP 64). Jednak dostrzega się także brak ciągłości, gdyż są przerwy w obowiązywaniu prawa (np. przepisy na temat zachowania czystego i nieczystego, przepisy pokarmowe, prawa dotyczące rozwodu, szabatu), a zastępuje je nowe prawo (NŻP 64). Brak ciągłości ma wprawdzie negatywne oblicze, ale należy pamiętać o stopniowym objawieniu i wypełnianiu go, choćby w nauce o Bogu, człowieku i ludzie Bożym (NŻP 65).

W głoszeniu orędzia Starego Testamentu w związku z przesłaniem Nowego Testamentu wielką pomocą jest znajomość wspólnych i podstawowych tematów, które występują w całym Piśmie Świętym, a są nimi: 1) objawienie Boże (Bóg przemawiający do ludzi, Bóg jedyny, Bóg Stwórca; Opatrzność ); 2) osoba ludzka, jej wielkość i nędza (stworzeni na obraz Boga, wielkość i nędza istoty ludzkiej); 3) Bóg: Wybawca i Zbawiciel; 4) wybór Izraela; 5) przymierze; 6) prawo; 7) modlitwa i kult, Jerozolima i świątynia; 8) Boże nagany i wyroki; 9) obietnice (Abraham, Ziemia Obiecana, trwałość przymierza i ostateczne zbawienie Izraela, królestwo Boże, Syn i następca Dawida) (NŻP 23-63) ${ }^{26}$. Powyższe perspektywy tematyczne, w tym także historiozbawcze, mogą bardzo pomóc kaznodziei w osobistym rozumieniu i przybliżaniu słuchaczom przesłania Starego Testamentu. Może przy tym wykazać ciągłość, brak ciągłości i postęp w przekazie zasadniczych wydarzeń i tematów zawartych w historii zbawienia (NŻP 64-65). Dokument Papieskiej Komisji Biblijnej wyraźnie wskazuje na związek pomiędzy Starym i Nowym Testamentem, co jest bardzo ważne dla kaznodziejów.

26 W. Schütz pisze, że klamrą, która łączy dwa Testamenty, są słowa: „Ty będziesz moim ludem, a ja będę twoim Bogiem", Probleme der Predigt..., dz. cyt., s. 84. 
Dodatkową pomocą służy Słownik teologii biblijnej ${ }^{27}$, który zawiera wiele haseł tematycznych ${ }^{28}$.

Najnowszy dokument Kongregacji ds. Kultu Bożego i Dyscypliny Sakramentów, Dyrektorium homiletyczne, wskazuje więc na jedność całego Pisma Świętego (DH 18-19, 23), na „głęboką więź, jaka łączy Stary i Nowy Testament" (DH 25). Dyrektorium wiele razy uwrażliwia kaznodziejów na związek, jaki zachodzi między czytaniami ze Starego Testamentu i ewangeliami w okresach roku liturgicznego, co wynika z założeń Lekcjonarza (DH 19, 25, 51, 57, 81, 146, 148). Liturgia słowa uwydatnia bowiem zasadę jedności całego Pisma Świętego. Dokument wskazuje też na spełnienie się Pisma (DH 21, 51), mówi, że Stary Testamentu należy odczytywać w świetle Tajemnicy Paschalnej (DH 24, 38), gdyż powiązanie obydwu Testamentów „ześrodkowane jest na Chrystusie i Jego misterium paschalnym" (DH 16, 23; VD 57) ${ }^{29}$.

W Dyrektorium homiletycznym (DH 23) czytamy: „Katechizm Kościoła Katolickiego jest nieocenionym źródłem dla głosiciela homilii [...] dostarcza nadzwyczajnego przykładu «jedności całego Pisma Świętego» [...] Indeks biblijny Katechizmu dowodzi, że całe nauczanie Kościoła przeniknięte jest słowem Biblii. Homileci mogą posługiwać się tym indeksem celem sprawdzenia, jak poszczególne teksty biblijne [w tym teksty ze Starego Testamentu], mogące stać się tematem ich przepowiadania, są użyte w innych kontekstach w celu pouczenia doktrynalnego i moralnego. Dodatek do Dyrektorium będzie dla homilisty pomocą w korzystaniu przezeń z Katechizmu". Jeżeli perykopa ze Starego Testamentu lub jej urywki występują w Katechizmie, to poznamy, w jakim kontekście i znaczeniu ich użyto, jaka jest ich teologiczna interpretacja.

27 Słownik teologii biblijnej, red. X. Léon-Dufour, tłum. z franc. K. Romaniuk, Poznań 1973.

28 Tamże, s. 1165-1168.

29 Zob. H. Sławiński, Znaczenie, geneza i struktura "Dyrektorium homiletycznego", „Polonia Sacra” 40 (2015) nr 3, s. 155-176. 
Należy zauważyć, że w dokumentach Kościoła spotykamy zdecydowane przeciwstawianie się fałszywym poglądom, formom marcjonizmu, jakoby należało zrezygnować z zajmowania się przesłaniem Starego Testamentu (VD 40; NŻP przedmowa, s. 6).

Trzeba jeszcze dodać, że dokumentem liturgicznym, który zobowiązuje kaznodzieję do głoszenia przesłania Starego Testamentu, jest Lekcjonarz mszalny. Jedność Pisma Świętego uwydatniają trzy czytania zestawione ze sobą w niedzielnym i świątecznym cyklu ABC. We wprowadzeniu do Lekcjonarza czytamy, że przez to „uwidacznia się jedność obydwu Testamentów i dziejów zbawienia, których ośrodkiem jest Chrystus wspominany w Jego misterium paschalnym" ${ }^{30}$.

Podsumowując, „pierwsze czytanie i Ewangelia uwidaczniają jedność obydwu Testamentów, a drugie czytanie z Dziejów Apostolskich, Listów, Apokalipsy wskazuje na interpretację i realizację objawienia w Kościele pierwotnym. Widać to szczególnie w liturgii wielkosobotniej, która zawiera czytania traktujące o takich wielkich dziełach Bożych jak stworzenie, przymierze, odkupienie. Nie można więc w trakcie posługi słowa odłączać Starego Testamentu od Nowego, skoro - jak się rzekło - całe Pismo Święte jest księgą chrześcijańską. Natomiast Stary Testament, chociaż stanowi osobną całość, bez Nowego byłby niezrozumiały, a nawet mógłby w pewnym stopniu być traktowany mitologicznie. Należy zatem w kazaniach rzetelnie przybliżać wiernym Stary Testament, kierując się wskazaniami biblistów i homiletów, którzy o tych sprawach piszą"31.

Widzimy więc, że Kościół bardzo troszczy się o właściwą interpretację Starego Testamentu w teologii i głoszeniu słowa Bożego, co powinno pobudzać homiletów i kaznodziejów do zgłębiania tego zagadnienia.

30 Lekcjonarz mszalny, t. I, Poznań-Warszawa 1972, s. 10.

31 J. Twardy, Aktualizacja..., dz. cyt., s. 111; zob. K. Müller, Homiletyka na trudne czasy, Kraków 2003, s. 96-103; H. M. Müller, Homiletik. Eine evangelische Predigtlehre, Berlin 1996, s. 226-237. 


\section{Historiozbawczy kontekst orędzia Starego Testamentu}

Z nauki Kościoła, współczesnej teologii i homiletyki wynika, że orędzie Starego Testamentu należy głosić w kontekście historii zbawienia. Trzeba zatem przybliżyć wskazania homiletyczne i ich znaczenie dla kaznodziejów. Bruno Dreher, który uwydatnił znaczenie Starego Testamentu w głoszeniu słowa Bożego, pisze, że do wprowadzenia nowego Ordo Lectionum w Kościele katolickim odczuwało się brak kazań na temat Starego Testamentu. Potrzeba tego rodzaju kazań „wynika z wewnętrznej jedności, jaka zachodzi pomiędzy Starym i Nowym Testamentem. Obydwie księgi zawierają jedną i tę samą historię zbawienia" ${ }^{32}$.

Homileci zaznaczają również, że w historii teologii były i takie sugestie, aby Stary Testament usunąć z głoszenia słowa Bożego lub potraktować jako księgę zamkniętą w sobie, która należy do Żydów. Takie poglądy pojawiały się w czasie od Marcjona przez Schleiermachera do Harnacka ${ }^{33}$. Trzeba jednak zdecydowanie odrzucić jakiekolwiek próby minimalizowania czy nawet odrzucania Starego Testamentu, co byłoby niezgodne z nauką Chrystusa i zasadami głoszenia Ewangelii (NŻP s. 6; VD 40). Wilfried Engemann zaznacza, że Chrystus nie odrywał swego nauczania od wiary i tradycji żydowskiej ${ }^{34}$. Z kolei Herbert Simon pisze: „Według Drehera Stary Testament bez odniesienia do Nowego będzie traktowany jako źródło «budujących przykładów moralizatorskich». Zaś Nowy Testament bez odniesienia do Starego staje się najczęściej «przepowiadaniem wielkich idei teologicznych i prawd religijnych z pominięciem historycznego objawienia,

32 H. Simon, Kazanie biblijne..., dz. cyt., s. 60; B. Dreher, Biblisch predigen..., dz. cyt., s. 63-64.

33 B. Dreher, Biblisch predigen..., dz. cyt., s. 64; W. Schütz, Probleme der Predigt..., dz. cyt., s. 81.

34 W. Engemann, Einführung..., dz. cyt., s. 283. 
co jest właśnie jego specyfiką" ${ }^{35}$. Kaznodzieja powinien pouczać, że Nowy Testament jest kontynuacją starotestamentowej historii zbawienia, jest wypełnieniem zawartych w niej zapowiedzi. Mówi o tym współczesna teologia i wskazują na to czytania liturgiczne. Dowodzą tego jednoznacznie liczne cytaty i aluzje do Starego Testamentu zawarte w czterech ewangeliach i w innych księgach Nowego Testamentu.

Można powiedzieć, że Nowy Testament jest ściśle związany ze Starym, a świadczy o tym dobitnie zestawienie liczbowe podane $\mathrm{w}$ dokumencie Papieskiej Komisji Biblijnej pt. Naród żydowski i jego Święte Pisma w Biblii chrześcijańskiej ${ }^{36}$. We wprowadzeniu do tego dokumentu podano liczbę cytatów pośrednich ze Starego Testamentu i aluzji do niego w następujących księgach: 160 w Ewangelii według Mateusza, 60 w Ewangelii według Marka, 192 w Ewangelii według Łukasza, 137 w Ewangelii według Jana, 140 w Dziejach Apostolskich, 72 w Liście do Rzymian. W sumie w czterech ewangeliach występuje 549 cytatów pośrednich i aluzji odnoszących się do Starego Testamentu. Dlatego najważniejszą zasadą, którą kaznodzieja ma uwzględniać, będzie zasada jedności obydwu Testamentów (KO 16). Obydwa Testamenty wzajemnie się wyjaśniają lub tłumaczą, a przez to uwydatniają one historiozbawczy charakter całej Biblii, jej ciągłość i zmierzanie ku eschatycznej pełni w Chrystusie. Trzeba więc mówić o historiozbawczym kontekście interpretacji orędzia Starego Testamentu. Na przykład wydarzenia w ogrodzie Eden ( $\mathrm{Rdz} 2$ - 3) otrzymują nowe światło w tekście Apokalipsy, który mówi: „[...] i ujrzałem niebo nowe i ziemię nową" (Ap 21, 1). Historiozbawcze świadectwo o znaczeniu Starego Testamentu wyznacza perspektywę w głoszeniu jego orędzia. Kurt Frör pisze, że w głoszeniu słowa Bożego należy także uwzględniać kontekst ogólnobiblijny, a w jego ramach teksty, które mają znaczenie historiozbawcze. Odnoszą się one do siebie na zasadzie struktury

35 H. Simon, Kazanie biblijne..., dz. cyt., s. 61.

36 Kielce 2002. 
polifonicznej, czyli wielowarstwowej, a z niej wyłania się wątek tematyczny, który występuje w różnych miejscach Biblii. Wspomniany autor określa te teksty mianem kontrapunktowych - kontrapunktische Texte ${ }^{37}$.

W świetle powyższych stwierdzeń kaznodzieja ma do dyspozycji wiele cytatów i aluzji ze Starego Testamentu, które występują w ewangeliach niedzielnych i w drugich czytaniach w cyklu ABC, a ponadto w lekcjonarzu na uroczystości i święta w ciągu trzech lat liturgicznych.

Wypełniania zasady jedności Pisma Świętego uczymy się od Jezusa Chrystusa, „który, głosząc tak centralne dla wiary tematy, jak: Królestwo Boże, Przymierze, krew, przybliżając tytuły mesjańskie (Syn Dawida, Król, Syn Człowieczy), łączył przecież Dobrą Nowinę ze Starym Testamentem" ${ }^{38}$. Chrystus jest najlepszym wzorem historiozbawczej interpretacji Starego Testamentu, gdyż wielokrotnie powoływał się na Pismo, mówił, że spełnia się ono na Jego osobie, swoim życiem wypełniał zapowiedzi proroków (NŻP 70-78). Głosząc Ewangelię, doskonalił dawne prawa, nadawał im nowego znaczenia: „A Ja wam powiadam: Każdy, kto się gniewa na swego brata, podlega sądowi” (Mt 5, 22). W ewangeliach spotykamy liczne logia Jezusa, w których występują cytaty ze Starego Testamentu i aluzje odnoszące się do Niego. Chrystus w swoim nauczaniu posługiwał się Starym Testamentem, który doskonale znał i pragnął, aby jego słuchacze również dobrze rozumieli te pisma. Dobra Nowina nie jest oderwana od korzeni, które tkwią w Starym Testamencie, ale jest ona jego kontynuacją i wypełnieniem. Swoim życiem i działalnością Chrystus wypełniał zapowiedzi mesjańskie, czynił to po śmierć na krzyżu, a po zmartwychwstaniu tłumaczył uczniom z Emaus, że musiało się

37 Wege zur Schriftauslegung. Biblische Hermeneutik für Unterricht und Predigt. Katholische von $\mathrm{H}$. Halbfas besorgte Lizenzausgabe unter dem veränderten Titel. 3 überarbeitete Aufl. Düsseldorf 1967, s. 337-339.

38 J. Twardy. Aktualizacja słowa Bożego..., dz. cyt., s. 111. 
spełnić Pismo (Łk 24, 25-26). Dzięki Chrystusowi zrozumiałe stały się zapowiedzi mesjańskie, a Stary Testament, będąc księgą żydowską, stał się księgą chrześcijańską i należy jej przesłanie głosić w duchu chrześcijańskim. Od Chrystusa uczymy się tłumaczenia i wyjaśniania Starego Testamentu, poprawnego głoszenia jego orędzia, wzywania słuchaczy do wypełniania go w życiu.

Chrystus urzeczywistnił to, co w Starym Testamencie znalazło zapowiedź przez osoby, rzeczy i wydarzenia ${ }^{39}$. Bez Chrystusa, bez Nowego Testamentu, Stary Testament byłby niepełny, niespełniony; w historii zbawienia zabrakłoby ciągłości - zostałaby zatrzymana w swoim biegu; zapowiedzi mesjańskie nadal czekałyby na spełnienie. Dopiero Chrystus nadał Staremu Testamentowi pełne znaczenie, przyniósł ludzkości pełnię objawienia i dokonał zapowiedzianego zbawienia. Stąd istotna jest chrystologiczna perspektywa w tłumaczeniu orędzia Starego Testamentu, które należy głosić w duchu Nowego Testamentu. W historiozbawczym głoszeniu przesłania Starego Testamentu obowiązuje zasada chrystocentryzmu, która jest naczelną zasadą całego kaznodziejstwa, odnosi się do wszystkich form posługi słowa Bożego ${ }^{40}$. W tym sensie Chrystus znajduje się w centrum objawienia Bożego i historii zbawienia.

Zasada chrystocentryzmu zawiera w sobie dwa spojrzenia lub kierunki hermeneutycznej interpretacji: 1) od Starego Testamentu po światło i wypełnienie w Nowym; 2) od Nowego Testamentu ku źródłom i zapowiedziom w Starym. Św. Augustyn wyraził to w następujący sposób: „Nowy Testament jest ukryty w Starym, natomiast Stary znajduje wyjaśnienie w Nowym” (cyt. za VD 41). Natomiast św. Grzegorz napisał: „To, co Stary Testament obiecał, Nowy ukazał; co tamten głosi skrycie, ten wyznaje otwarcie jako już obecne. Dlatego Stary Testament jest proroctwem Nowego Testamentu; a najlepszym

39 H. Simon, Kazanie biblijne..., dz. cyt., s. 62.

40 Zob. W. Schütz, Probleme der Predigt..., dz. cyt., s. 85. 
komentarzem do Starego Testamentu jest Nowy Testament" ${ }^{41}$. Kaznodzieja nie może jednak sugerować lub podsycać tryumfalizmu religii chrześcijańskiej nad judaizmem ${ }^{42}$.

„Pierwszymi głosicielami Chrystusa byli żydzi i dlatego szukali wyjaśnienia Jego tajemnicy w swojej księdze, czyli w Starym Testamencie. Stąd też w Nowym Testamencie spotykamy liczne nawiązania do Starego, tzw. cytaty refleksyjne, gdyż wówczas, w odległych stuleciach, miał duże znaczenie argument skrupturystyczny" ${ }^{43}$. Apostołowie, autorzy ksiąg Nowego Testamentu, są wzorem głoszenia orędzia Starego Testamentu, czego dowodzą stosowane przez nich cytaty refleksyjne i aluzje związane z tą częścią Pisma Świętego. Naśladowali oni Chrystusa w głoszeniu Ewangelii powiązanej z pismami Starego Przymierza, aktualizowali słowo Boże w życiu Kościoła pierwotnego.

Podstawowa zasada hermeneutyczna mieści się w hitoriozbawczej perspektywie: zapowiedź i przygotowanie - wypełnienie w Chrystusie - ku eschatycznej pełni, której obrazem jest nowe niebo i nowa ziemia (Ap 21, 1). Stąd zasada jedności Pisma Świętego wskazuje na eschatyczną kontynuację wypełnienia w Chrystusie. Ta perspektywa historiozbawcza łączy się ściśle z chrystologią, gdyż dopiero Chrystus doskonale wyjaśnił Stary Testament i nadał mu pełnego znaczenia w kontekście Nowego Przymierza ${ }^{44}$.

Trzeba jednak z rozwagą i umiarem w posłudze słowa kierować się zasadą zapowiedź-wypełnienie, gdyż nie jest ona jedyną i powszechną w tłumaczeniu Pisma Świętego; wprawdzie wiele tekstów Nowego

41 Cyt. za VD 40 przyp. 139. Oto słowa św. Augustyna: „Novum Testamentum in Vetere latet, Vetus autem in Novo patet" - „Nowy Testament kryje się w Starym, Stary Testament odsłania się w Nowym". Zob. Z. Pilch, Wykład zasad, s. 290.

42 W. Engemann, Einführung..., dz. cyt., s. 283.

43 J. Twardy, Aktualizacja..., dz. cyt., s. 111. Zob. np. Ewangelia wg św. Mateusza rozdz. 3-5; Dzieje Apostolskie rozdz. 2; Papieska Komisja Biblijna, Naród żydowski i jego Święte Pisma w Biblii chrześcijańskiej, Kielce 2002, s. 17, przyp. 2-6.

44 W. Schütz, Probleme..., dz. cyt., s. 82. 
Testamentu na nią wskazuje, zwłaszcza List do Rzymian: „A przecież kresem Prawa jest Chrystus, który przynosi usprawiedliwienie każdemu, kto wierzy" (Rz 10, 4). Byłby to jednak uproszczony schemat, gdyż nie wszystkie starotestamentowe teksty są zapowiedzią czegoś, co ma swoje wypełnienie w Nowym Przymierzu. Chociaż w wielu tekstach jest analogia, kontynuacja, czy wskazanie, nie należy jednak za wszelką cenę doszukiwać się wypełnienia Starego Testamentu w Nowym ${ }^{45}$. Herbert Simon pisze: „Współczesna egzegeza każe również homilecie unikać «zbyt jednoznacznie chrystologicznego wyjaśniania tekstów Starego Testamentu». Teksty Starego Testamentu odnoszą się nie tylko do samego Chrystusa, ale także do całej rzeczywistości Nowego Testamentu - do Boga, zbawienia, etosu nowotestamentowego, wspólnoty, sakramentów i naśladowania Chrystusa" ${ }^{46}$.

Stary Testament zawiera bardzo obfite treści wyrażone przy pomocy wielu starożytnych gatunków literackich. Niejednokrotnie teksty te są obce współczesnemu człowiekowi i trzeba ułatwić mu ich zrozumienie, tłumaczyć pojęcia, obrazy i symbole ${ }^{47}$. W Starym Testamencie występują liczne opisy cudów i wymagają, aby kaznodzieja mówił o nich w ramach historii zbawienia, nie zaś głównie w kontekście przyrodniczym, jako zawieszaniu lub przekraczaniu praw natury. Cuda te są bowiem znakami Objawienia, wskazują na zbawcze działanie Boga; człowiek zaś powinien odpowiadać na nie przez wiarę i posłuszeństwo Jego słowu. Kaznodzieja powinien także starannie pouczać słuchaczy o wielkiej roli proroków, ich wiernym głoszeniu słowa Bożego i bezkompromisowej trosce o wiarę i moralność narodu wybranego ${ }^{48}$.

45 H. Simon, Kazanie biblijne..., dz. cyt., s. 63; B. Dreher, Biblisch predigen..., dz. cyt., s. 70.

46 H. Simon, Kazanie biblijne..., dz. cyt., s. 63-64; B. Dreher, Biblisch predigen..., dz. cyt., s. 68-69.

47 F. Winter, Die Predigt..., dz. cyt., s. 251-252.

48 T. Dzięgiel, Stary Testament w posłudze słowa..., dz. cyt., s. 132-134. 
Przybliżając wiernym orędzie Starego Testamentu, kaznodzieja będzie pamiętał, że czynili to już ojcowie Kościoła, obficie czerpali z tych Ksiąg, ale w tłumaczeniu tekstu nieraz przesadnie posługiwali się interpretacją alegoryczną i za często dopatrywali się sensu typologicznego ${ }^{49}$. Wyjaśniając Stary Testament, kaznodzieja zachowa ostrożność w posługiwaniu się interpretacją alegoryczną, chociaż św. Paweł mówi o niej w Liście do Galatów 4, 21-31, wskazując na niewolnicę i Hagar. Jednak w dokumencie Papieskiej Komisji Biblijnej czytamy: „wówczas chodzi faktycznie o typologię, to znaczy, że osoby wymienione w starym tekście są przedstawione jako zapowiedź przyszłych rzeczywistości” (NŻP 20). Kaznodzieja powinien z tekstów zaczerpniętych ze Starego Testamentu wydobywać sens wyrazowy, duchowy i pełniejszy, a nie narzucać tym perykopom interpretację alegoryczną (NŻP 20, IBK II B 1-3) ${ }^{50}$.

\section{4. Łączenie tekstów starotestamentowych z tekstami nowotestamentowymi}

Kaznodzieja najczęściej spotyka się z gotowym zestawem czytań zawartych w Lekcjonarzu niedzielnym i świątecznym. Natomiast przygotowując się do głoszenia homilii obrzędowej, może wybrać z Lekcjonarza czytanie ze Starego Testamentu i połączyć je z odpowiednią ewangelią. Również przy pomocy słownika teologii biblijnej lub konkordancji może natrafić na interesujące powiązania tekstów ze Starego i Nowego Testamentu.

Wilfried Engemann ${ }^{51}$ podaje cztery modele interpretacji Starego Testamentu, które uwydatniają teologiczną konfrontację z orędziem

49 B. Dreher, Biblisch predigen..., dz. cyt., s. 69.

50 H. Simon, Kazanie biblijne..., dz. cyt., s. 63; B. Dreher, Biblisch predigen..., dz. cyt., s. 69.

51 W. Engemann, Einführung..., dz. cyt., s. 282-289. 
Nowego Testamentu. Chodzi mu o korelację między przesłaniem tekstów starotestamentowych i nowotestamentowych, która uwydatnia objawienie Boże i jedność historii zbawienia.

1. Model retrospekcyjny zakłada, że prawidłowe rozumienie Starego Testamentu możliwe jest jedynie przez spojrzenie od Nowego Testamentu wstecz. Dlatego schemat tego modelu opiera się na związku pomiędzy obietnicą i wypełnieniem. Czytając Stary Testament pod kątem objawienia dokonanego w Chrystusie, można mówić o historiozbawczym znaczeniu modelu retrospektywnego, gdyż uwydatnia on powiązanie obydwu Testamentów. Nie można jednak pochopnie i arbitralnie posługiwać się tym modelem w interpretacji Starego Testamentu, ale trzeba brać pod uwagę różnorodność, cel i kontekst zawartych w nim tekstów. Jednostronne byłoby też traktowanie proroków głównie jako wieszczów przyszłości z pomijaniem tego, że odważnie walczyli o czystość wiary. Również w Starym Testamencie napotykamy na obietnice i ich wypełnienie. W końcu lektura Starego Testamentu powinna pomagać w odnoszeniu jego przesłania do życia człowieka ${ }^{52}$.

2. Model opozycyjny polega na przeciwstawianiu prawa Starego Testamentu i Ewangelii Nowego Testamentu. Jednak Stary Testament nie utożsamia się z prawem, a Nowy nie jest tożsamy z łaską. Model opozycyjny jest niezgodny $\mathrm{z}$ historią, gdyż pierwotni chrześcijanie chodzili do synagogi i byli również związani ze Starym Przymierzem. Z kolei Nowy Testament, podobnie jak i Stary, ukazuje historię zbawczego działania Boga. W Starym Testamencie jest także działanie łaski, a konieczność przyjęcia Ewangelii nie wynika tylko z istnienia prawa, ale dzięki Chrystusowi wierność prawu otrzymuje swój nowy fundament ${ }^{53}$. Stąd też ograniczone znaczenie ma interpretacja oparta na przeciwstawianiu tekstów ze Starego i Nowego Testamentu.

52 Tamże, s. 284-285.

53 Tamże, s. 285-286. 
3. Model dynamiczny oparty jest na stopniowaniu wyrazistości w przybliżaniu pełni Bożego zbawienia w drodze od Starego Testamentu do Nowego. Bóg tworzy historię zbawienia razem ze swoim ludem; nie stoi ona $\mathrm{w}$ miejscu, ale podlega dynamicznym procesom i prowadzi do ostatecznego wypełnienia. Słowo Boże odznacza się żywotnością: zostało podane w obfitości i podlega ciągłej interpretacji aż Chrystus powtórnie przyjdzie. Wskazuje to również na dynamikę, moc i żywotność wiary ${ }^{54}$.

4. W modelu analogii nie odróżnia się metody interpretacji Starego i Nowego Testamentu. W obu przypadkach chodzi o świadectwo $\mathrm{z}$ dawnych czasów podane $\mathrm{w}$ obcym języku, chociaż w różnych sytuacjach życiowych. Rozpatrując analogię między Starym i Nowym Testamentem, można traktować teksty w ten sposób, jakby były napisane dla nas, a sytuacje i doświadczenia egzystencjalne kiedyś i dzisiaj były do siebie podobne, czyli analogiczne, np. cierpienie, zwątpienie, nadzieja, zaufanie. Teksty te trzeba uaktualnić, gdyż służą one pogłębieniu kontaktu z Bogiem, umocnieniu wiary, mają znaczenie dla życia człowieka. Analogiczne perykopy wykazują, że Bóg ludu izraelskiego jest Ojcem Jezusa Chrystusa, że można porównywać wiarę Izraela w jedynego Boga $\mathrm{z}$ wiarą Kościoła - lub podobnie porównywać wiarę i życie poszczególnych ludzi w obu Testamentach. Podobnie jak w życiu Izraela konieczny był Bóg, tak i w naszym życiu konieczny jest Chrystus. Jednak analogie nie oznaczają identyfikacji, np. wędrującego ludu przez pustynię nie można utożsamiać z Kościołem, a raczej ta wędrówka stanowi analogię życia chrześcijańskiego po narodzeniu Chrystusa. Teksty analogiczne będą odpowiedzią na pytanie: kim jest Jezus dla nas dzisiaj? Starotestamentowe teksty wskazują w końcu na Chrystusa, na wiarę, grzech, królestwo Boże $e^{55}$. 
Omówione cztery modele interpretacji Starego Testamentu, w konfrontacji z Nowym, rzucają wiele światła i mogą być pomocne w pracy kaznodziei. Powinien on jednak rozważnie posługiwać się nimi, czynić to zgodnie ze zdobyczami hermeneutyki biblijnej, aby nie narzucać tekstom natchnionym interpretacji niezgodnej z ich założeniami literackimi i celem teologicznym.

W Konstytucji o Objawieniu Bożym czytamy: „Ekonomia Starego Testamentu zmierzała nade wszystko ku temu, aby przygotować przyjście Chrystusa, Odkupiciela wszystkich ludzi, oraz mesjańskiego królestwa, proroczo je zapowiedzieć (por. Łk 24, 44; J 5, 39; 1 P 1, 10) i wyrazić je w obrazach typicznych (por. 1 Kor 10, 11" (KO 15). Papież Benedykt XVI pisze: „Lektura typologiczna odsłania niewyczerpaną treść Starego Testamentu w odniesieniu do Nowego" (VD 41). Interpretacja ta odgrywa bardzo istotną rolę w przybliżaniu słuchaczowi biblijnej historii zbawienia, gdyż wiąże się z prawdą o jedności całego Pisma Świętego i z zasadą zapowiedź-wypełnienie ${ }^{56}$. Tłumaczenie typologiczne polega na dostrzeganiu w osobach, wydarzeniach, czynnościach, instytucjach Starego Testamentu ich zapowiedzi i znaków dla przyszłości. „W myśl takiego ujęcia osoby, figury, instytucje, wydarzenia i czynności ze Starego Testamentu, obok swego własnego znaczenia, są znakami, obrazami i zapowiedzią rzeczy przyszłych, które się pojawią dopiero w Nowym Testamencie" 57.

„W apostolskiej posłudze słowa w Kościele wczesnochrześcijańskim wskazywano, że różne typy lub figury znajdują spełnienie w Jezusie Chrystusie. Prawdopodobnie istniały wówczas tzw. Testimonia, czyli świadectwa obecności Starego Testamentu w Nowym, w których świetle można było lepiej rozumieć naukę i zbawcze dzieło Chrystusa. Kaznodzieja ma jednak pamiętać, że typologiczny wykład Pisma

56 J. Twardy, Aktualizacja..., dz. cyt., s. 113-115.

57 Tamże, s. 113. Zob. H. Langkammer, Słownik biblijny, Katowice 1984, s. 151; J. Homerski, Biblijna hermeneutyka, w: Encyklopedia katolicka, t. II, k. 466-467; A. Jankowski, Przy stole słowa 1. Adwent. Boże Narodzenie, s. 9-11. 
Świętego należy stosować ostrożnie i że musi mieć pełne uzasadnienie biblijne, tym bardziej, że typologiczna interpretacja nie jest wyłącznym sposobem jego wyjaśnienia. Wprawdzie warto dodać, że niektórzy ojcowie Kościoła dostrzegali więcej typów i widzieli je szerzej, ale kaznodzieja nie może się tymi uwagami kierować" ${ }^{58}$. Autorzy ksiąg Nowego Testamentu wskazują na poniższe typy:

Adam (Rdz 2, 17; 3, 11) - Chrystus (Rz 5, 14); Abel (Rdz 4, 10) Abel przez ofiarę jeszcze przemawia (Hbr 11, 4), krew Jezusa przemawia mocniej niż krew Abla ( $\mathrm{Hbr} 12,24)$; wody potopu (Rdz 7, 7) woda chrztu (1 P 3, 20-21); wiara Abrahama ( $\operatorname{Rdz} 22$, 15-18) - wiara chrześcijanina (Rz 4, 18-25); krew Baranka (Wj 13; Kpł 8, 15. 24. 30; Wj 24, 8) - Krew Chrystusa (Hbr 9, 11-28); Izrael (Oz 11, 1) - Chrystus, „Z Egiptu wezwałem Syna mego" (Mt 2, 15); wąż miedziany na palu (Lb 21, 4-9) - Chrystus na krzyżu (J 3, 14-18); Baranek paschalny (Wj 12, 46) - Chrystus na krzyżu: „Kość jego nie będzie złamana” (J 19, 36); Baranek zabity (Wj 12, 1-13) - „Chrystus bowiem został złożony w ofierze jako nasza Pascha” (1 Kor 5, 7); Jonasz (Jon 2, 1n; 3, 3) - Chrystus (Mt 12, 39-41); woda ze skały (Lb 20, 8-11) - Chrystus, źródło życia (1 Kor 10, 4); kapłaństwo Melchizedeka (Rdz 14, 17-20) kapłaństwo Chrystusa (Hbr 7, 1-28); Jeruzalem ziemskie (Ez 48) Jeruzalem niebieskie (Ap 21, 9-21); eschatologiczna chwała Jeruzalem (Za 14, 1-21) - eschatologiczna chwała Jeruzalem (Ga 4, 22-26).

58 J. Twardy, Aktualizacja..., dz. cyt., s. 113. Zob. H. Langkammer, Słownik biblijny, s. 152; A. J. Levoratti, Interpretacja Pisma Świętego, w: Międzynarodowy komentarz do Pisma Świętego. Komentarz katolicki i ekumeniczny na XXI wiek, red. Farmer, Warszawa 2000, s. 25-26; J. Stępień, Sens biblijny, w: Podręczna encyklopedia biblijna, red. E. Dąbrowski, t. II, Poznań 1959, s. 505-506; Z. Pilch, Wykład zasad kościelnej wymowy, s. 306-307; W. Dommershausen, Bibelerklärung, Bibel-Lexikon, red. H. Haag, Einsiedeln 19682, k. 214; A. Tyrrell Hanson (pp), Typologia, w: Słownik wiedzy biblijnej, red. B. M. Metzger, M. D. Coogan, tłum. z ang. A. Karpowicz [i in.], Warszawa 1987, s. 780-781; A. Baum, Typologia, Praktyczny słownik biblijny, red. A. Grabner-Haider, Warszawa 1995, k. 1339-1340; B. McNeil, Typologia, w: Słownik hermeneutyki biblijnej, red. R. J. Houlden, tłum. z ang. B. Widła, Warszawa 2005, s. 894-895. 
Zestawione antytypy i typy biblijne często występują w liturgii ${ }^{59}$ i są „bardzo pomocne w przybliżaniu głębokich, obrazowych i pouczających treści chrystologicznych. Warto je wykorzystywać w kazaniach (i katechezach), a przez to uwydatniać chrystocentryczny charakter historii zbawienia. Należy też pamiętać, że typ starotestamentowy jest niedoskonały i przejściowy w odniesieniu do swojego odpowiednika w Nowym Testamencie" 60 .

W liturgii słowa na niedziele i święta szereg razy występuje zestawienie czytań na zasadzie: zapowiedź-wypełnienie, co również powinno inspirować kaznodzieję do akcentowania historii zbawienia. Celowe byłoby przeanalizowanie pod tym kątem całego Lekcjonarza, opracowanie odpowiedniego zestawienia, co jednak przekracza rozmiary niniejszego artykułu. Na przykład w IV niedzielę Adwentu B czytamy perykopę: 2 Sm 7, 1-5. 8b-12. 14a. 16, a w niej słowa Pana odnoszące się do Dawida: „Przede Mną dom twój i twoje królestwo będzie trwać na wieki. Twój tron będzie utwierdzony na wieki” (2 Sm 7, 16). Słowa te spełniły się na Chrystusie, o którym anioł Gabriel powiedział Maryi: „Pan Bóg da Mu tron Jego praojca, Dawida. Będzie panował nad domem Jakuba na wieki, a jego panowaniu nie będzie końca” (Łk 1, 32-33). Stanie się tak dlatego, gdyż Mesjasz jest Wcielonym „Synem Najwyższego” (Łk 1, 32) ${ }^{61}$.

59 Np. w takie dni, jak: Ur. N. Pocz. NMP, NMP Matki Kościoła; 1n. W. Postu A i B; 2 n. W. Postu B; 3 n. W. Postu C; W. Czwartek; Ur. Najśw. Ciała i Krwi Chrystusa B; 7 N. Wielkanocy C; 3 n. zw. B; 31 n. zw. B; Św. Podwyższenia Krzyża.

60 J. Twardy, Aktualizacja..., dz. cyt., s. 113-115.

61 W III niedzielę Adwentu C, w perykopie z Al. 35, 1-6a. 10 są słowa: „Wtedy przejrzą oczy niewidomych i uszy głuchych się otworzą. Wtedy chromy wyskoczy jak jeleń i język niemych wesoło krzyknie" (Iz 35, 5-6). Ewangelia (Mt 11, 2-11) natomiast zawiera słowa Chrystusa wypowiedziane do uczniów Jana Chrzciciela: „Idźcie i oznajmijcie Janowi to, co słyszycie i na co patrzycie: niewidomi wzrok odzyskują, chromi chodzą, trędowaci doznają oczyszczenia, głusi słyszą, zmarli zmartwychwstają, ubogim głosi się Ewangelię" (Mt 11, 4-5). Tak więc cuda Jezusa są znakami Jego mesjańskiej godności i zbawczego posłannictwa. J. Twardy, Głoszenie cudów Jezusa, s. 53-54. W Wielki Piątek czytamy proroctwo Izajasza o cierpiącym Słudze Pańskim (52, 13 - 53, 12), a spełnieniem tych słów jest Męka 
Mówiąc o wypełnieniu Starego Testamentu w życiu i nauczaniu Chrystusa, o ile to możliwe, dobrze będzie wskazywać także na ostateczną pełnię tego zbawczego działania. Herbert Simon pisze: „Aby kaznodzieja mógł należycie odczytać kerygmat tekstów Starego Testamentu, winien w opracowaniu tych tekstów stosować raczej zasadę «historii i obietnicy» (Geschichte und Verheißung), która zdaniem Drehera jest najbardziej miarodajna w uchwyceniu korelacji obu Testamentów" ${ }^{2}$. Objawienie Boże jest dynamiczne, zawiera w sobie obietnice i stopniowo odsłania coraz to nowe horyzonty zbawcze. Dlatego pomiędzy obydwoma Testamentami istnieje realna ciągłość wydarzeń i faktów zbawczych. Chociaż w Chrystusie spełniły się mesjańskie zapowiedzi, to jednak dzieje zbawienia trwają i czekamy na ich ostateczne wypełnienie. Wcielenie i misterium paschalne zapowiadają nowe perspektywy zbawcze i ich wypełnienie w paruzji Chrystusa. Stąd też według św. Pawła, chociaż zmartwychwstanie jest już dokonane, to jednak trzeba ciągle na nie oczekiwać: „I jak w Adamie wszyscy umierają, tak też w Chrystusie wszyscy będą ożywieni, lecz każdy według własnej kolejności: Chrystus jako pierwociny, potem ci, co należą do Chrystusa, w czasie Jego przyjścia" (1 Kor 15, 22-23) ${ }^{63}$.

Chrystusa w opisie czterech ewangelistów. Chrystus jest bowiem Mesjaszem cierpiącym, co sam kilkakrotnie zapowiedział. Uwydatniają tl.np. teksty z $24 \mathrm{n}$. zw. al.: Iz 50, 5-9a i Mk 8, 27-35.

62 H. Simon, Kazanie biblijne..., dz. cyt., s. 64.

63 Tamże, s. 64; Dreher, Biblisch predigen, s. 73. Na przykład w 10 zwykłą niedzielę C czytamy tekst o wskrzeszeniu dziecka przez proroka Eliasza i Ewangelię o wskrzeszeniu młodzieńca z Nain (Łk 7, 11-17), co ma wydźwięk historiozbawczy, gdyż Chrystus jest zmartwychwstaniem i życiem (J 11,25), zwycięża śmierć i obdarza ludzi tym zwycięstwem (2 Tm 1, 10; 1 Kor 15, 57). Kiedyś „przywróci do życia nasze śmiertelne ciała" (Rz 8, 11), "jako ostatni wróg zostanie pokonana śmierć" (1 Kor 15, 24). „I otrze z ich oczu wszelką łzę, a śmierci już nie będzie” (Ap 21, 4). Przy pomocy wybranych tekstów można w homilii uwydatniać historiozbawczą dynamikę przesłania tekstów Starego Testamentu, ich ukierunkowanie eschatologiczne w Nowym. 
W ten sposób zasada «historii i obietnicy» pozwala lepiej zrozumieć dynamikę Starego Testamentu, jego znaczenie w historii zbawienia. Teksty Starego Testamentu są ciągle aktualne, bo uczą także spojrzenia eschatycznego, gdyż wcielenie, męka i zmartwychwstanie Chrystusa już się dokonały ${ }^{64}$. Dlatego głoszenie przesłania tekstów Starego Testamentu ma trzy etapy: 1) kerygmat tekstu; 2) jego związek z tekstami nowotestamentalnymi; 3) aktualizacja kerygmatu. Pracując w ten sposób nad homilią, kaznodzieja będzie korzystał z liturgii słowa na niedziele i święta lub wybierze odpowiednie teksty z czytań biblijnych zawartych w obrzędach sakramentów. We właściwym łączeniu czytań ze Starego Testamentu z perykopami z Nowego pomocne będą trzy rodzaje harmonizacji: 1) historiozbawcza (o ile wyraźnie występuje), 2) teologiczno-tematyczna, 3) teologiczno-parenetyczna.

1. „Kierując się harmonizacją historiozbawczą, uwydatniamy perspektywę historii zbawienia, co czynimy przy pomocy trzech lub przynajmniej dwu czytań wedle zasady: zapowiedź w Starym Testamencie realizacja w Chrystusie [...]. Na przykład przy udzielaniu sakramentu chrztu wybierzemy trzy następujące czytania: I. (Wj 17, 3-7) - Woda wypływająca ze skały; II (1 Kor 12, 12-13) - «Wszyscy też zostaliśmy napojeni jednym Duchem»; Ewangelia: (J 7, 37b-39), - «Jeśli ktoś jest spragniony [...] niech przyjdzie do Mnie i pije»" ${ }^{65}$. Ułatwi to słuchaczom spojrzenie na Stary Testament pod kątem historii zbawienia.

64 H. Simon, Kazanie biblijne..., dz. cyt., s. 65.

65 „Możemy użyć także dwu czytań: I. (Ez 36, 24-28) - O nowym Duchu, który uzdolni do życia według przykazań i Ewangelii (Mk 12, 28b-34a) na temat przykazania miłości, którego wypełnianie «znaczy daleko więcej niż wszystkie całopalenia i ofiary» (Mk 12, 33). Jako drugie czytanie może posłużyć paralelny tekst, zaczerpnięty z Ewangelii św. Mateusza (22, 35-40), który wskazuje, że«na tych dwu przykazaniach opiera się całe Prawo i Prorocy» (Mt 22, 40). Jeżeli kaznodzieja dobrze uwrażliwi się na harmonizację historiozbawczą, to będzie ją realizował również w homiliach niedzielnych i świątecznych, nie ograniczy się do jednego czytania, najczęściej do Ewangelii, ale uwzględni i należycie wykorzysta perykopę ze Starego Testamentu". J. Twardy, Aktualizacja..., dz. cyt., s. 121. 
2. „Stosując teologiczno-tematyczną harmonizację tekstów biblijnych, można uwydatniać teologiczną treść danego sakramentu, co jest ważne w homilii obrzędowej. "Czytania zestawiamy w taki sposób, aby ukazywały jeden aspekt teologiczny sakramentu, wzajemnie się dopełniały lub wyjaśniały. Wymaga to znajomości centralnych tematów teologicznych sprawowanego sakramentu» ${ }^{66}$. Na przykład przy udzielaniu sakramentu chrztu istotna jest symbolika wody, która oznacza oczyszczenie i nawrócenie. Kaznodzieja kierując się tym tematem ma możliwość Ewangelię o źródle wody żywej (J 7, 37b-39a) zharmonizować z tekstem, który mówi o wyprowadzeniu wody ze skały na pustyni przez Mojżesza (Wj 17, 3-7)"67.

3. Przykładem harmonizacji teologiczno-parenetycznej może być zestawienie czytania I z Ewangelią na 6 niedzielę zwykłą C. Tekst z Jeremiasza 17, 5-8 mówi o mężu (człowieku) przeklętym, „który pokłada nadzieję w człowieku" (Jr 17, 5) i o mężu (człowieku) błogosławionym, „który pokłada ufność w Panu, i Pan jest jego nadzieją" (Jr 17, 7). Natomiast Chrystus wypowiada cztery razy „błogosławieni” i cztery razy „biada” na określenie dobrej i błędnej nadziei ludzkiej (Łk 6, 17. 20-26). Może więc kaznodzieja powiedzieć o chrześcijańskiej cnocie nadziei i jej zaprzeczeniu, co jest bardzo aktualne w dobie materializmu i konsumpcjonizmu. Należy zaznaczyć, że „W czytaniach biblijnych nie spotyka się jednak pouczeń wyłącznie dogmatycznych, albo wyłącznie moralnych, są one ze sobą powiązane,

66 J. Twardy, Jak w seminariach..., dz. cyt., s. 49.

67 „Podobnie tekstem - związanym tematycznie ze wspomnianą Ewangelią - może być perykopa o wodzie, która wypływała «spod progu świątyni» (Ez 47, 1-9. 12) albo perykopa (1 Kor 12, 12-13), w której są słowa: «Wszyscy bowiem w jednym Duchu zostaliśmy ochrzczeni, [aby stanowić] jedno Ciało: czy to Żydzi czy Grecy, czy niewolnicy, czy wolni. Wszyscy też zostaliśmy napojeni jednym Duchem» (1 Kor 13). Kaznodzieja, dostrzegając tematyczny związek wybranych czytań, może również w niedziele głosić biblijno-teologiczne homilie, które będą spójne pod względem treści i zarazem aktualne." J. Twardy, Aktualizacja..., dz. cyt., s. 121-122. 
a wnioski moralne wypływają z głębokiej teologii. Widać to w tekstach św. Pawła i św. Jana"68.

\section{Wskazania i wnioski}

1. Kaznodzieja posługuje się lekcjonarzem na niedziele, uroczystości i święta, w którym na ogół I czytanie zaczerpnięto ze Starego Testamentu ( $w$ niedziele wielkanocne I czytanie zaczerpnięte jest z Dziejów Apostolskich). Powinien zatem dobrze poznać przesłanie tekstu ze Starego Testamentu, w czym pomoże mu znajomość kontekstu bliższego i dalszego, miejsc paralelnych i realiów biblijnych. Następnie ma odkryć tematyczny związek, jaki zachodzi pomiędzy czytaniem I i Ewangelią dnia, uwydatniając historię zbawienia. W niej zaś może mieć miejsce powiązanie na zasadzie zapowiedzi w Starym Testamencie i wypełnienie w Chrystusie lub na zasadzie perspektywy eschatycznej. Częściej natomiast wystąpi historiozbawcze powiązanie teologiczno-tematyczne lub teologiczno-parenetyczne pomiędzy tekstami ze Starego Testamentu i ewangeliami. W poznawaniu tego związku, czytania I i Ewangelii, pomogą kaznodziei krótkie tytuły lub hasła zamieszczone w lekcjonarzu przed czytaniami. Jeżeli zaś I czytanie w jakiś sposób wiąże się z II, należy to również uwzględnić w posłudze słowa.

2. W głoszeniu orędzia Starego Testamentu bardzo ważne jest, aby kaznodzieja dostrzegał liczne cytaty ze Starego Testamentu i aluzje do jego treści, które występują w Nowym, a szczególnie w ewangeliach, czy nawet w II czytaniu. W poznawaniu orędzia czytania I, jak i pozostałych czytań, nie wystarczy sam lekcjonarz, gdyż zawiera on teksty wyjęte z kontekstu. Należy zatem wziąć do ręki Pismo Święte Nowego Testamentu z zaznaczonymi odnośnikami do Starego i odwrotnie,

68 J. Twardy, Jak w seminariach..., dz. cyt., s. 49. 
Stary Testament z odnośnikami do Nowego. Kaznodzieja powinien mieć do dyspozycji komentarze do Starego Testamentu, słowniki teologii biblijnej, Pismo Święte z zaznaczonymi cytatami i aluzjami ze Starego Testamentu w Nowym, a także konkordancję biblijną, aby mógł wyszukiwać tematyczne miejsca paralelne w Piśmie Świętym. Nieodzowne jest także poznawanie dokumentów Kościoła, które dotyczą Starego Testamentu i jego związku z Nowym. Dzięki takiemu studium kaznodzieja łatwiej wniknie w historiozbawcze znaczenie Starego Testamentu i całego Pisma Świętego. Ułatwi przez to realizowanie założeń podanych w Dyrektorium homiletycznym.

3. W myśl zasady historiozbawczej należy w doborze czytań perykopę ze Starego Testamentu łączyć z Ewangelią. Chodzi tu o wybór czytań związanych ze sprawowaniem sakramentów i sakramentaliów. Liturgia słowa zawiera bowiem liczne czytania ze Starego Testamentu, ale stosunkowo rzadko posługują się nimi kaznodzieje. Istotne jest dostrzeganie typologii biblijnej, która pomoże uwydatnić, jak Stary Testament wiąże się z Nowym. Dzięki obrazowym i konkretnym antytypom i typom pomożemy słuchaczom wniknąć w głębię biblijnej historii zbawienia, odkrywać działanie Boga w dziejach ludzkości. Powinniśmy też objaśniać wiernym nawiązania do Starego Testamentu, które występują w pieśniach kościelnych, a szczególnie w Godzinkach o Niepokalanym Poczęciu Maryi Panny.

4. W przybliżaniu orędzia Starego Testamentu trzeba podejmować główne tematy przewodnie, które występują również w Nowym Testamencie, a w którym mają one swoją kontynuację. Te węzłowe bloki tematyczne uwydatniają bieg historii zbawienia, wskazują na postęp i przemiany, jakie zaszły w przekazie objawienia biblijnego, w wydarzeniach zbawczych i głoszeniu słowa Bożego. W ramach historii zbawienia dostrzegamy ruch ku doskonałości, a także odchodzenie od starego Prawa i wprowadzanie nowego. Dlatego kaznodzieja będzie chętnie korzystał z pomocy do teologii biblijnej, aby poznawać główną tematykę historiozbawczą. 
5. W głoszeniu słowa Bożego pomocne jest korzystanie z licznych modlitw zawartych w Starym Testamencie. Psalmy responsoryjne tłumaczą i aktualizują orędzie I czytania, uczą modlitewnej refleksji nad nim, tym bardziej, że je śpiewamy. Z Księgi Psalmów zaczerpnie kaznodzieja wiele modlitw zawsze aktualnych w różnych doświadczeniach, przeżyciach i sytuacjach egzystencjalnych człowieka, jak np. radość, uwielbienie i dziękczynienie, troska, ból, żal za grzechy, cierpienie, załamanie, ucisk, udręczenie, choroba, miłość, wiara nadzieja itd. W księgach Starego Testamentu napotkamy także na wiele innych modlitw, które warto wykorzystać w kaznodziejstwie. A trzeba pamiętać, że najdoskonalszym wzorem modlitwy jest Jezus Chrystus, który modlił się słowami ze Starego Testamentu, np. na krzyżu wypowiedział słowa z Psalmu 22, 2: „Boże mój, Boże mój, czemuś Mnie opuścił" (Mt 27, 46).

6. Stary Testament mówi też o wielu wzorach wiary, takich jak np. Abraham (Rdz 18-22), Eleazar (2 Mch 9, 18-31), siedmiu braci i ich matka (2 Mch 7, 1-42). Te i inne teksty, zawarte są w liturgii słowa i można je wykorzystywać w głoszeniu homilii, konferencji rekolekcyjnych, nauk stanowych, kiedy to przybliżamy słuchaczom wzory wiary kobiet, mężczyzn, matek i ojców. W Starym Testamencie napotkamy również na teksty odpowiednie do kazań dla młodzieży. Starotestamentowe wzory życia moralnego są nadal aktualne, tym bardziej, gdy te opisy wiążą się z kerygmatem Nowego Testamentu.

Mamy obowiązek wskazywać na ścisłą jedność Starego i Nowego Testamentu, bo jedno jest słowo Boże, a dzieje zbawienia trwają i ogarniają coraz to nowych ludzi i narody. Dzięki przybliżaniu orędzia Starego Testamentu wzbudzimy u słuchaczy głębsze zrozumienie Biblii i pogłębimy u nich szacunek dla słowa Bożego. Otworzymy przez to wiernym skarbiec biblijny i zaprosimy ich do obficie zastawionego stołu słowa Bożego. Akcentując znaczenie Starego Testamentu, będziemy prowadzić słuchaczy do Nowego Testamentu i wskażemy na ciągłą nowość, aktualność i nieprzemijającą wartość Ewangelii. 
Dlatego głoszenie starotestamentowego słowa Bożego nie jest zamknięte $\mathrm{w}$ sobie, ale wprost albo pośrednio prowadzi do proklamacji Słowa Wcielonego. W głoszeniu słowa Bożego trzeba kierować się więc zasadą tota Scriptura - całe Pismo Święte, co wymaga właściwego traktowania orędzia Starego Testamentu: „[... korzenie chrześcijaństwa znajdują się w Starym Testamencie i chrześcijaństwo zawsze czerpie pokarm z tych korzeni” (VD 40).

\section{Głoszenie orędzia Starego Testamentu. Refleksje homiletyczne}

Streszczenie

W polskiej homiletyce rzadko występuje refleksja na temat głoszenia kerygmatu Starego Testamentu, często zaś rozwijają ją homileci niemieckiego obszaru językowego, których publikacje wykorzystał m.in. autor artykułu. O doniosłości badanego problemu mówią współczesne dokumenty Kościoła, a wśród nich Verbum Domini i Dyrektorium homiletyczne, które wskazują na to, aby w głoszeniu orędzia Starego Testamentu opierać się na jedności Pisma Świętego i uwzględniać zasadę chrystocentryzmu, a także dobrze pojętą interpretację typologiczną. Omawiane orędzie biblijne mieści się w kontekście historii zbawienia, ma swoją dynamikę zbawczą, wymaga wiernej interpretacji i trafnej aktualizacji egzystencjalnej. Należy zatem poprawnie łączyć teksty czerpane ze Starego Testamentu z perykopami nowotestamentowymi, czynić to w oparciu o ich związek historiozbawczy, parenetyczny lub teologiczno-tematyczny. W konfrontacji orędzia Starego Testamentu z Nowym i uwydatnianiu wzajemnych powiązań pomocne będzie posługiwanie się następującymi modelami interpretacyjnymi: retrospekcyjnym, opozycyjnym, dynamicznym i opartym na analogii. Właściwe i częste przybliżanie przesłania Starego Testamentu wzbogaci treść homilii i innych form kaznodziejstwa, uwrażliwi słuchaczy na wielkie znaczenie słowa Bożego.

Słowa kluczowe

Stary Testament, kerygmat biblijny, historia zbawienia, homiletyka materialna, hermeneutyka biblijna 


\section{Proclamation of the Message of the Old Testament. Homiletical Reflections}

\section{Summary}

Reflection on proclamation of kerygma of Old Testament rarely appears in Polish homiletics, but it is often emphasized by the homilets of the German language area; such publications have been referred to by the author of the article. How important the problem is state the contemporary documents of the Church - among them Verbum Domini and Homiletic Directory which demand that the unity of the Bible, principle of Christocentrism, as well as rightly defined typological interpretation should be considered in Old Testament proclamation. The presented biblical message is located within the context of history of salvation, has its salvific dynamics, needs the right interpretation and accurate existential actualization. The texts drown from Old Testament should be correctly connected with New Testament pericopes based on their relation of historical parenetic or theological and thematic nature. The following interpretation models: retrospective, opposing, dynamic and based on analogy will be helpful in confrontation between message of Old and New Testament and emphasis of their reciprocal connections. The message of Old Testament should be often and appriopriately presented in homilies and other forms of preaching; this way the faithful will be sentisized to the great significance of God's Word.

Keywords

Old Testament, biblical kerygma, history of salvation, material homiletics, biblical hermeneutics

\section{Bibliografia}

Bobicz I., Źródła kaznodziejstwa. Pismo Święte, w: Homiletyka duszpasterska, Kielce 1935, s. 167-219.

Conrad R., Weber M., Protestantische Predigtlehre, Tübingen 2012.

Die vergessene Wurzel. Das Alte Testament in der Predigt der Kirchen, red. R. Zerfaß, H. Poengsen, Würzburg 1990.

Dreher B., Biblisch predigen, Stuttgart 1968. 
Dzięgiel T., Stary Testament w posłudze słowa, "Materiały Problemowe” 10 (1978) nr 6, s. 127-134.

Engemann W., Einführung in die Homiletik, Tübingen 2002.

Frör K., Wege zur Schriftauslegung. Biblische Hermeneutik für Unterricht und Predigt. Katholische von $\mathrm{H}$. Halbfas besorgte Lizenzausgabe unter dem veränderten Titel. 3 überarbeitete Aufl. Düsseldorf 1967.

Gryniakow J., Teksty Starego Testamentu w homiletyce chrześcijańskiej, „Rocznik Teologiczny ChAT" 28 (1986) nr 1, s. 21-35.

Hirschler H., Biblisch predigen, Hannover 1923.

Klippert W., Vom Text zur Predigt, Wuppertal 1995.

Krynicki W., Wymowa święta, Poznań 19212.

Mildenberger F., Kleine Predigtlehre, Stuttgart 1984.

Müller H. M., Homiletik. Eine evangelische Predigtlehre, Berlin 1996.

Müller K., Homiletyka na trudne czasy, tł. z niem. M. Mijalska, Kraków 2003.

Nübold E., Zur Auswahl der Perikopen des Alten Testaments in der nachkonziliaren katholischen Perikopenordnung, w: Die vergessene Wurzel. Das Alte Testament in der Predigt der Kirchen, red. R. Zerfaß, H. Poengsen, Würzburg 1990, s. 29-42.

Pilch Z., Wykład zasad kościelnej wymowy, Poznań 1958.

Poengsen H., Was macht die christliche Predigt aus dem Alten Testament, w: Die vergessene Wurzel. Das Alte Testament in der Predigt der Kirchen, red. R. Zerfaß, H. Poengsen, Würzburg 1990 s. 9-28.

Schütz W., Probleme der Predigt, Göttingen 1981.

Simon H., Kazanie biblijne. Teoria przepowiadania Bruno Drehera (1911-1971), Opole 1995.

Sławiński H., Znaczenie, geneza i struktura „Dyrektorium homiletycznego", „Polonia Sacra" 40 (2015) nr 3, s. 155-176.

Trillhaas W., Evangelische Predigtlehre, Aufl. 4, München 1955.

Twardy J., Aktualizacja słowa Bożego w kaznodziejstwie, Przemyśl 2009.

Twardy J., Głoszenie cudów Jezusa dzisiaj, Kielce 2001.

Twardy J., Jak w seminariach duchownych przygotowywać do głoszenia homilii obrzędowej, „Przegląd Homiletyczny” 9 (2005), s. 41-54.

Winter F., Die Predigt, w: Handbuch der Praktischen Theologie, Bd. 2, red. H. Ammer [i in.], Berlin 1974, s. 199-312.

Zerfass R., Texte und Kontexte. Zur Erschließung alttestamentlicher Perikopen im Predigtgespräch, w: Die vergessene Wurzel. Das Alte Testament in der Predigt der Kirchen, red. R. Zerfaß, H. Poengsen, Würzburg 1990, s. 174-191. 
Ziemer J., Der Text, w: Handbuch der Predigt, red. K. H. Bieritz [i in.], Berlin 1990, s. 207-242. 